\author{
ZBIGNIEW ZIOLO \\ Uniwersytet Pedagogiczny w Krakowie - Pedagogical University of Cracow, Poland \\ Podkarpacka Szkoła Wyższa w Jaśle - Podkarpacka Higher Education School in Jasło, Poland
}

\title{
Model roli przedsiębiorczości w procesie kształtowania układów regionalnych
}

\author{
Model of the Role of Entrepreneurship in the Process of Formation \\ of Regional Structures
}

Streszczenie: Wstępnie przyjmujemy założenie, że w celu racjonalnego kształtowania struktur regionalnych niezbędne są studia dotyczące struktury funkcjonalnej ich elementów, określania uwarunkowań ich rozwoju, a także zachodzących między nimi relacji. Na tym tle celem analizy jest: próba modelowego określenia uwarunkowań działalności małych firm, zasad ich lokalizacji i rozwoju w strukturze regionalnej, określenie ich funkcji, wewnętrznych relacji aktywnych i pasywnych zachodzących między nimi, a także między nimi a elementami otoczenia. Wśród podstawowych elementów struktury regionalnej wyróżniono elementy przyrodnicze, społeczno-ekonomiczne i kulturowe, a następnie określono ich funkcje, konkurencyjność firm w zakresie wykorzystania zasobów, obszary rynkowe, politykę społeczno-gospodarczą, jakość polityki, jakość elit i instrumentów prawnych.

\begin{abstract}
We initially assume that in order to rationally form regional structures, it is indispensable to conduct studies of the functional structure of their elements, determining the conditions of their development, as well as relations between them. Against this setting, the purpose of the analysis is: an attempt to model determine the operational conditions of small business, principles of their location and development in the regional structure, determining their function, internal active and passive relations taking place between them as well as with elements of the environment. Among the basic elements of the regional structure there have been singled out: natural elements, socio-economic and cultural, and next determined were their functions, competitiveness of companies in the use of resources, market areas, socio-economic policy, quality of policy, quality of elites and legal instruments.
\end{abstract}

Słowa kluczowe: elementy regionu; małe przedsiębiorstwa; region ekonomiczny; region społeczno-gospodarczy; reguły rozwoju; uwarunkowania rozwoju

Keywords: conditioning of development; development rules; economic region; elements of the region; socio-economic region; small enterprises

Otrzymano: 30 marca 2018

Received: 30 March 2018

Zaakceptowano: 25 września 2018

Accepted: 25 September 2018 


\section{Sugerowana cytacja/Suggested citation:}

Zioło, Z. (2018). Model roli przedsiębiorczości w procesie kształtowania układów regionalnych. Przedsiębiorczość - Edukacja [Entrepreneurship-Education], 14, 11-25. DOI: 10.24917/20833296.14.1

\section{Wstęp}

W warunkach rozwijającej się gospodarki rynkowej znacznie zwiększa się rola władz samorządowych układów regionalnych w zakresie wyznaczania kierunków rozwoju społeczno-gospodarczego i kulturowego, a ich głównym celem winno być dążenie do systematycznego podnoszenia poziomu i jakości życia ludności. W tym zakresie ważnym problemem, przed którym stoją zarówno władze, jak i społeczeństwo, jest dążenie do najefektywniejszego wykorzystania istniejących zasobów oraz poprawa uwarunkowań dla generowania wewnętrznych i przyciągania zewnętrznych czynników rozwoju. Umożliwia to pobudzanie społecznych postaw przedsiębiorczych przez rozwijanie aspiracji i budowanie kapitału ludzkiego i społecznego (Kamińska, Heffner, 2010; Zioło, 2010). Kapitał ten w zasadniczym stopniu umożliwia konsolidację społeczną układów regionalnych skierowaną na podejmowanie racjonalnych działań w zakresie wzrostu gospodarczego, a także rozwoju społecznego i kulturowego. Układy regionalne stanowią złożone struktury składające się z wielu różnorodnych elementów działalności gospodarczej i instytucji, które spełniają w nich określone funkcje, a celem ich działalności winno być pobudzanie i stymulowanie procesów rozwoju. Wyłania się stąd bardzo ważny problemem dla prac badawczych i działań aplikacyjnych, którym jest dążenie do coraz precyzyjniejszego poznania złożonego mechanizmu procesów rozwojowych układów regionalnych. Powinny one służyć stawianiu racjonalnych celów, budowaniu najlepszych strategii rozwoju oraz podejmowaniu decyzji dla ich realizacji w procesie zarządzania (Dobrowolska, 1948, 1962; Kudłacz, 1999; Zioło, 2017). W kształtowaniu tego procesu podstawową rolę odgrywa odpowiednio przygotowany człowiek o wysokiej moralności oraz wykształconych cechach przedsiębiorczych, który jest zdolny do stawiania i realizowania założonych, a zarazem najbardziej korzystnych celów rozwojowych. W świetle przedstawionych przesłanek przedmiotem niniejszych rozważań jest próba określenia miejsca podmiotów gospodarczych osób fizycznych w strukturze funkcjonalnej układów regionalnych. Rozważania oparto na bogatym dorobku prac prezentowanych i dyskutowanych na konferencjach naukowych i publikowanych w czasopismach: Zakładu Przedsiębiorczości i Gospodarki Przestrzennej Instytutu Geografii Uniwersytetu Pedagogicznego „Przedsiębiorczość Edukacja”, Akademii Ignatianum w Krakowie - „Horyzonty Wychowania” (Wach, 2014a, 2014b; Pasierbek, Wach, 2016), licznych pracach podejmujących tę problematykę (np. Bajgier-Kowalska, Tracz, Uliszak, 2016, Dominiak, 2016; Kiniorska, Wrońska-Kiczor, 2016; Płaziak, Rachwał, 2014, 2015; Sowiślok, 2016) oraz na własnych doświadczeniach badawczych (Zioło, 2015, 2016).

\footnotetext{
${ }^{1}$ Do tej pory ukazało się 13 tomów studiów poświęconych roli przedsiębiorczości: we współczesnych wyzwaniach cywilizacyjnych, w podnoszeniu konkurencyjności społeczeństwa i gospodarki, w aktywizacji gospodarki, w rozwoju gospodarki opartej na wiedzy, kształtowaniu społeczeństwa informacyjnego, procesach integracji europejskiej, nasilających się procesach globalizacji, edukacji i rozwoju układów przestrzennych.
} 
Problematyka badawcza regionu ekonomicznego wskazuje na bardzo dużą złożoność i rozpatrywana jest z wielu punktów widzenia, wyrazem czego jest bogata literatura przedmiotu (Zioło, 2017). Obecnie region ekonomiczny (region społeczno-ekonomiczny lub społeczno-gospodarczy) traktowany jest jako przedmiot poznania i badania, jako narzędzie analizy przestrzennej oraz narzędzie organizacji i działania społecznego (Dziewoński, 1971: 79). W kształtowaniu struktur regionalnych ważną rolę odgrywa realizacja określonych koncepcji rozwojowych, które w znacznym stopniu zależą od wykształconych postaw przedsiębiorczych elit władzy i dojrzałości społeczeństwa.

W celu racjonalnej organizacji przestrzeni danego kraju obok wielu typów regionów wyróżnia się także region administracyjny. Obejmuje on terytorialną część gospodarki narodowej, charakteryzującą się nie tylko całością gospodarczo-społeczną, ale przede wszystkich jednością administracyjną oraz posiadaniem jednolitych organów władzy administracyjnej (Berezowski, 1988; Fajferek, 1966; Kudłacz, 1999; Harańczyk, 2011, 2012; Kudełko, 2007; Zioło, 2017). Przyjmuje się, że reprezentują go obecne województwa, a w ich analizie powinno się uwzględniać wewnętrzne zróżnicowanie społeczne i ekonomiczne. W mniejszym stopniu powinno się brać pod uwagę administracyjne układy powiatowe, ale ze względu na dostęp do bazy informacyjnej powiaty często traktowane są jako podstawowe przestrzenne jednostki strukturalne. Bardziej precyzyjny obraz zróżnicowania przestrzennego obszaru województwa otrzymuje się w wyniku przyjęcia jako podstawowej jednostki przestrzennej gminy lub podstawowych jednostek osadniczych (Kudełko, 2003, 2013; Zaucha, Szlachta 2015; Śleszyński, Bański, Degórski, Komornicki, 2017).

\section{Wpływ elementów przestrzeni regionalnej na funkcjonowania podmiotów gospodarczych}

W układach regionalnych procesy rozwoju działalności podmiotów gospodarczych osób fizycznych realizują się w wyniku wykształconych społecznych postaw przedsiębiorczych oraz $\mathrm{w}$ określonych uwarunkowaniach związanych z położeniem w przestrzeni przyrodniczej i poziomem rozwoju społecznego, gospodarczego i kulturowego (ryc. 1). W pracach badawczych należy przyjąć, że współczesne zróżnicowanie poziomu rozwoju układów regionalnych jest wynikiem kształtowania się ich struktur gospodarczych, społecznych i kulturowych w zróżnicowanych uwarunkowaniach, które zmieniały się w historycznym procesie wzrostu (Dobrowolska, 1948, 1962; Kudełko, 2013).

Ważnymi czynnikami lokalizacji i rozwoju działalności gospodarczej są poszczególne elementy przestrzeni przyrodniczej, które charakteryzują się określonymi cechami o odpowiednim poziomie atrakcyjności dla rozwijania eksploatacji i przetwórstwa zasobów surowcowych, możliwości rozwoju ruchu turystycznego, a także które ze względu na swoją unikalność mogą stanowić cenne pomniki przyrody wymagające szczególnej ochrony. Wśród uwarunkowań przyrodniczych podstawowe znaczenie mają podłoże geologiczne o określonych zasobach surowcowych, które może być wykorzystane w procesie gospodarowania, oraz właściwości techniczne podłoża dla podejmowania działalności inwestycyjnej. Warunki klimatyczne, zwłaszcza kierunki wiatrów, rozkład temperatury, opady i wilgotność, umożliwiają wyznaczanie miejsc lokalizacji działalności gospodarczej. Zasoby wód powierzchniowych i podziemnych wpływają na możliwości wykorzystania ich jako zasobów w procesach technologicznych, w lecznictwie, ciepłownictwie, do żeglugi śródlądowej, mogą też stanowić określone rezerwuary wodne 
Ryc. 1. Uwarunkowania i reguły podmiotów gospodarczych osób fizycznych

\begin{tabular}{|c|c|c|}
\hline & \multicolumn{2}{|c|}{ Elementy układu regionalnego } \\
\hline \multirow{35}{*}{ 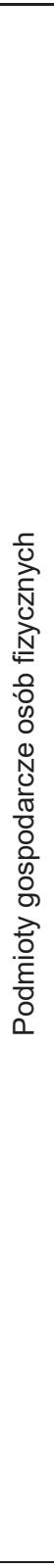 } & \multirow{4}{*}{$\begin{array}{l}\text { Elementy przestrzeni } \\
\text { regionalnej (M) }\end{array}$} & przyrodnicze \\
\hline & & społeczne \\
\hline & & gospodarcze \\
\hline & & kulturowe \\
\hline & \multirow{4}{*}{$\begin{array}{c}\text { Funkcje elementów } \\
\text { regionalnych: podmioty } \\
\text { gospodarcze, instytucje (C) }\end{array}$} & podstawowe (wiodące) \\
\hline & & komplementarne \\
\hline & & \begin{tabular}{|l|} 
standardowe \\
\end{tabular} \\
\hline & & lokalne \\
\hline & \multirow{4}{*}{$\begin{array}{c}\text { Konkurencyjność w zakresie } \\
\text { wykorzystania zasobów } \\
\text { regionalnych }(\mathrm{K})\end{array}$} & przestrzennych \\
\hline & & zasoby pracy \\
\hline & & infrastruktury \\
\hline & & kapitałowych \\
\hline & \multirow{4}{*}{ Otoczenie regionu, rynki $(\mathrm{O})$} & światowe \\
\hline & & grupy krajów (UE) \\
\hline & & krajowe \\
\hline & & $\begin{array}{l}\text { innych regionów, układów } \\
\text { lokalnych }\end{array}$ \\
\hline & \multirow{5}{*}{$\begin{array}{c}\text { Reguły rozwoju } \\
\text { ekonomicznego (N) }\end{array}$} & reguły rozwoju światowego \\
\hline & & magaekonomii \\
\hline & & makroekonomiczne \\
\hline & & mezoekonomiczne \\
\hline & & mikroekonomiczne \\
\hline & \multirow{5}{*}{$\begin{array}{l}\text { Polityka: światowa, } \\
\text { europejska, krajowa, } \\
\text { regionalna }(P)\end{array}$} & gospodarcza \\
\hline & & społeczna \\
\hline & & międzynarodowa \\
\hline & & regionalna, lokalna \\
\hline & & ekologiczna \\
\hline & \multirow{5}{*}{$\begin{array}{c}\text { Jakość elit politycznych } \\
\text { władzy: ustawodawczej, } \\
\text { wykonawczej, sądowniczej } \\
\text { (W) }\end{array}$} & światowych \\
\hline & & europejskich \\
\hline & & krajowych \\
\hline & & regionalnych \\
\hline & & lokalnych \\
\hline & \multirow{4}{*}{$\begin{array}{c}\text { Instrumenty prawne: } \\
\text { pobudzające, stymulujące, } \\
\text { hamujące }(\mathrm{S})\end{array}$} & organizacji światowych \\
\hline & & Unii Europejskiej \\
\hline & & krajowe \\
\hline & & regionalne \\
\hline
\end{tabular}

Źródło: opracowanie własne 
(zwłaszcza wody podziemne). Ukształtowanie powierzchni może stanowić zarówno korzystne uwarunkowania dla rozwoju działalności gospodarczej, jak i stwarzać określone bariery w zakresie dostępności przestrzennej. Korzystny wpływ wywiera ono np. na rozwój pasterstwa, turystyki, rekreacji i wypoczynku, ale mniej korzystny - na procesy inwestycyjne, w których znaczny udział w kosztach mają nakłady przeznaczone na niwelację terenu, konieczność utwardzania terenu dla budowy infrastruktury i obiektów produkcyjno-usługowych, a także stwarza utrudnienia dla rozwijania komunikacji między jednostkami osadniczymi oraz ich otoczeniem. Warunki glebowe w podstawowym stopniu wpływają na kierunki i intensywność prowadzenia działalności rolniczej, zwłaszcza rozwijania upraw i hodowli.

Dla rozwoju przedsiębiorczości i działalności gospodarczej duże znaczenie mają także elementy społeczno-gospodarcze. Struktura rolnictwa może umożliwiać rozwój produkcji towarowej, która stanowić będzie źródło dochodów gospodarstw domowych, ale może być ona podejmowana tylko na potrzeby gospodarstwa domowego. Potencjał przedsiębiorstw przemysłowych oraz nowoczesność produkowanych wyrobów, a także jakość sieci usług materialnych i instytucjonalnych, mogą stwarzać korzystne możliwości lokalizacji i rozwoju działalności gospodarczej osób fizycznych poprzez wzajemne ich powiązania w zakresie produkcji, kooperacji lub działalności usługowej. Ważną rolę jako czynnik rozwoju odgrywa poziom zagospodarowania w infrastrukturę komunikacyjną (transportową, łączności), która dla podmiotów gospodarczych i ludności stwarza określone możliwości powiązań z otoczeniem regionalnym, krajowym i międzynarodowym. Tendencje przemian struktur demograficznych mogą stwarzać dogodne warunki dla wykorzystywania potencjalnych zasobów pracy, ale też mogą wpływać na ich ograniczanie w wyniku starzenia demograficznego lub nadmiernej emigracji, zwłaszcza ludzi młodych o wyższych kwalifikacjach zawodowych. Znaczącym czynnikiem możliwości rozwijania działalności gospodarczej osób fizycznych jest jakość sieci osadniczej, zwłaszcza jej skupienie bądź rozproszenie. Wpływa ono na różny stopień dostępności społeczeństwa do miejsc pracy i instytucji, oddziałuje na koszty utrzymania jednostek osadniczych, co może przyczyniać się do rozwijania działalności gospodarczej związanej z utrzymaniem odpowiedniego stanu technicznego oraz remontami infrastruktury sieciowej (drogowej, energetycznej, wodno-kanalizacyjnej, burzowej, utrzymanie ruchu). Istotnym elementem dla rozwoju działalności podmiotów gospodarczych jest wielkość zasobów kapitałowych i finansowych gospodarstw domowych, podmiotów gospodarczych i instytucji, które tworzą lokalne i ponadlokalne, a także regionalne rynki dla oferowanych przez nich produktów i usług. Wielkość zasobów finansowych tworzy dla podmiotów gospodarczych określone rozmiary rynku i może wpływać na jego rozszerzanie, pogłębianie, kurczenie się lub zanik. Zmieniające się uwarunkowania rynku lokalnego i regionalnego wymagają od podmiotów dużej elastyczności w zakresie zmian profilu działalności, kumulowania kapitału czy zmian lokalizacji działalności w układzie regionalnym, a nawet krajowym lub międzynarodowym².

\footnotetext{
${ }^{2}$ Przykładem może być firma informatyczna Asseco z Rzeszowa, która z firmy o funkcjach regionalnych rozwinęła się w firmę światową, działającą na wszystkich kontynentach. Podstawowe znaczenie w jej rozwoju mają postawa przedsiębiorcza, wysokie kwalifikacje i wizja założyciela, który w procesie zarządzania potrafi łączyć tworzenie i wdrażanie nowoczesnych produktów, nowych, oryginalnych metod zarządzania, umiejętnościami zachowań konkurencyjnych, przejmowania innych podmiotów tej branży lub nawiązywanie ścisłej współpracy oraz pogłębianie istniejących i opanowywanie nowych rynków.
} 
W procesie kształtowania działalności gospodarczej duże znaczenie mają elementy kulturowe, które w układach regionalnych w odmiennym stopniu wpływają na rozwój przedsiębiorczości i prowadzenie działalności gospodarczej osób fizycznych. Szczególną rolę w tym względzie odgrywają: kultura materialna, kultura duchowa, aspiracje społeczeństwa, poziom wykształcenia, zasoby intelektualne oraz świadomość społeczna i polityczna. Kultura materialna, upodobania, mody (np. budowy i wyposażania mieszkań, ubioru, konsumpcji), wyznaczają zasoby finansowe ${ }^{3}$. Nadmierne i nieracjonalne zadłużanie wynika z braku poszanowania podstawowej zasady ekonomii, która mówi, że nasze potrzeby są nieograniczone, ale możliwości ich realizacji są ograniczone. Stanowi ona również ważną przesłankę dla podejmowania decyzji dotyczących działalności gospodarczej. Podstawowe znaczenie dla rozwijania przedsiębiorczości mają aspiracje i plany życiowe poszczególnych osób, rodzin i społeczeństwa. Stanowią one także podstawę określania kierunków rozwoju układów regionalnych przez przedstawicieli władz administracyjnych, politycznych, organizacji pozarządowych i innych. Znaczącą podstawę dla rozwoju aspiracji i kształtowania planów życiowych stanowi poziom wykształcenia, który z kolei wpływa na jakość zasobów intelektualnych społeczeństwa układu regionalnego. Zasoby te umożliwiają rozwijanie i podnoszenie na wyższy poziom kapitału ludzkiego i społecznego, który jest ważną podstawą dla rozwoju przedsiębiorczości i podejmowania działalności gospodarczej. W budowaniu kapitału społecznego ważną rolę odgrywa wzajemne zaufanie do siebie poszczególnych osób, a także zaufanie do władz samorządowych, administracyjnych, politycznych, pozarządowych i innych. Podstawową rolę w tym zakresie odgrywa kultura duchowa, która określa wyznawanie przyjętych wartości uznawanych przez poszczególne religie, świeckie poglądy filozoficzne czy niezależne poglądy poszczególnych osób. W zależności od uznawanych zasad proponują one przyjmowanie określonych wzorców zachowań, którymi mogą kierować się zarówno poszczególne jednostki, jak i grupy społeczne (wyznaniowe) czy społeczności układów regionalnych. Dla katolików podstawowym układem odniesienia są dwa przykazania miłości, na których opiera się nadany przez Boga dekalog, zawierający także wcześniej przyjmowane przez ludzkość zasady prawa naturalnego. To z niego wynikają zasady etyki normatywnej. W oparciu o nie w uproszczeniu można przyjąć regułę: Postępuj tak, jak byś chciał, aby wszyscy postępowali w stosunku do ciebie.

Przedstawione elementy kulturowe są podstawą kształtowania świadomości społecznej, w której ważną rolę odgrywa wzajemne zaufanie dotyczące tworzenia warunków mających na celu podnoszenie jakości poziomu życia społeczeństwa w różnej skali układach przestrzennych. Można przyjąć, że realizacja zasad dekalogu wyeliminowałaby negatywne zjawisko rosnącej dysproporcji ekonomicznej, które z jednej strony wynika $\mathrm{z}$ nadmiernego wyzysku występującego w procesach gospodarowania, w tym głównie niskich płac, oraz wykorzystywania po niskich cenach zasobów surowców mineralnych krajów słabiej rozwiniętych, a z drugiej strony prowadzi do nadmiernej koncentracji kapitału

\footnotetext{
${ }^{3}$ Prowadzi to do natywnych zachowań, zwłaszcza ludzi młodych. Reklama konsumpcji w mediach oraz łatwość udzielania kredytów przez instytucje finansowe wpływają na rosnące zadłużanie się. Według Krajowego Rejestru Długów zadłużenie ludzi w wieku 18-25 lat zwiększyło się z 309 mld zł w 2016 r. do 535 mln zł w marcu 2018 r., tj. do 173,1\%. Wśród nich 55\% zadłużenia przypada na osoby w wieku 24-25 lat, a najwyższym zadłużeniem charakteryzuje się osoba w wieku 24 lat, która ma do oddania 625 tys. zł. Dominują osoby, które zaciągają pożyczki na zaspokojenia drogich zachcianek, na które ich nie stać, najczęściej na wakacje w ciepłych krajach, markowe ubrania, drogi sprzęt elektroniczny itp. (Ćwiek, 2018a, 2018b).
} 
w ręku nielicznej grupy osób ${ }^{4}$. Działania te wpływają na postępujący proces polaryzacji przestrzennej i społecznej, który przejawia się w nadmiernej dysproporcji potencjału ekonomicznego wśród grup społecznych i układów przestrzennych, co prowadzi do narastających niezadowoleń społecznych, przejawiających się w buntach pewnych grup społecznych czy społeczności regionalnych, a w krańcowej postaci - w rewolucjach społecznych.

Uwarunkowania te tworzą przesłanki dla rozwijania świadomości politycznej opartej na zasadach demokracji. Współcześnie dość powszechnie posługujemy się terminem „demokracja”, ale bez większego zrozumienia. Wywodzi się on ze starożytnej Grecji i związany jest z pojęciem „polityka”, którym określano sztukę zarządzania państwem. Arystoteles przyjmował, że polityka jest filozofią rządzenia, sposobem, w jaki zorganizowane jest społeczeństwo, przy czym politycy stanowią dodatek do społeczeństwa cywilnego - obywatelskiego. Natomiast zadaniem państwa jest tworzenie warunków do zapewnienia szczęśliwego życia. Cele polityki realizowali uczestnicy demokracji ateńskiej, którymi w tym czasie mogli być: mężczyźni, ludzie wolni (dysponujący określonymi zasobami materialnymi) i wykształceni, którzy ukończyli 30 rok życia (czyli będący już w fazie dojrzałości społecznej). Demokratyczny wybór dokonywał się w oparciu o reguły konkurencji intelektualnej osób starających się o wybór do władz. Służyły temu publicznie głoszone poglądy i toczone dyskusje, podczas których prezentowano cele, koncepcje oraz strategie i metody ich realizacji. Dzięki tym mechanizmom, w wyniku konkurencji intelektualnej, do zarządzania i sprawowania władzy wybierano osoby najlepiej przygotowane. Oznacza to, że w obecnych warunkach konieczne jest dbanie o systematyczne podnoszenie poziomu świadomości społeczeństwa w celu podejmowania przez nie: w celu podejmowania przez nie wyboru wyboru przedstawicieli władz na podstawie programów, w których ważną rzeczą musi być odpowiedź na pytanie, co zostanie zrobione, aby podnieść poziom i jakość życia poszczególnych osób, grup społecznych w układach lokalnych, regionalnych i krajowych, a także w układach europejskim i światowym. Wydaje się, że pojawiające się obecnie niezadowolenia społeczne i chęci separatystyczne wywołane są brakiem realizacji tego podstawowego celu. Elementy te wieńczy świadomość kulturowa, która przejawia się m.in. w umiejętności współżycia społecznego, wzajemnym szacunku do różnych wzorców zachowań, a także dorobku wykształconym w procesie rozwoju wśród różnych grup społecznych.

\section{Struktura funkcjonalna podmiotów gospodarczych układu regionalnego}

Struktura regionalna odznacza się dużym zróżnicowaniem poszczególnych elementów zarówno pod względem rozmiarów potencjału ekonomicznego, jak i spełnianych funkcji. Generalnie można w niej wyróżnić elementy o funkcjach: podstawowych (wiodących), komplementarnych, standardowych i lokalnych. Funkcje podstawowe spełniają

\footnotetext{
${ }^{4}$ Jak wynika z badań organizacji charytatywnej Oxfam, w latach 2007-2017 liczba milionerów na świecie zwiększyła się z $27 \mathrm{mln}$ do $36 \mathrm{mln}$. Z bogactwa wytworzonego w 2017 r. 82\% przejął 1\% najbogatszych, a 3,7 mld ludzi się nie wzbogaciło. Prezes jednej z największych marek modowych w ciągu jednego dnia zarabia tyle, ile pracownica szwalni z Bangladeszu zarabia przez całe życie. Z szacunków Banku Credit Suisse wynika, że w latach 2016-2017 liczba najbogatszych osób skupiających majątek, jakim dysponuje biedniejsza część połowy społeczeństwa, zmniejszyła się z 61 do 42, co podkreśla szybkie tempo wzrostu koncentracji kapitału. Według World Economic Forum, narastające nierówności są jednym z największych zagrożeń dla gospodarki i świata (Maciejewicz, 2018).
} 
podmioty gospodarcze i instytucje pracujące na potrzeby otoczenia międzynarodowego i krajowego ${ }^{5}$. Funkcje komplementarne spełniają podmioty pracujące na potrzeby elementów podstawowych. Funkcje standardowe spełniają podmioty gospodarcze i instytucje pracujące na potrzeby regionalne i ponadregionalne, natomiast funkcje lokalne - jednostki pracujące na potrzeby zespołu gmin, poszczególnych gmin, wsi czy osiedli. Na procesy rozwoju działalności podmiotów gospodarczych i instytucji obok przedsiębiorców znaczący wpływ wywierają instrumenty bezpośredniego i pośredniego oddziaływania, a także władze administracyjne województw, powiatów czy gmin. Mogą one stwarzać pewne zachęty dla powstawania i intensyfikowania działalności gospodarczej określonych podmiotów, które następnie będą wpływać na podnoszenie ich pozycji konkurencyjnej w strukturze krajowej, np. w zakresie generowania wewnętrznych czynników rozwoju, przyciągania zewnętrznych czynników, a także będą wpływać na podnoszenie poziomu i jakości życia ludności. Szczególne znaczenie ma w tym zakresie rozwój działalności edukacyjnej, której zadaniem jest przygotowanie odpowiednich kadr, podnoszenie zasobów intelektualnych społeczeństwa, rozwój i poprawa jakości działalności instytucji finansowych, ochrona zdrowia, wypoczynku i inne. W strukturach regionalnych między wyróżnionymi kategoriami elementów wykształcają się różnego rodzaje relacje, np.: produkcyjne, usługowe, instytucjonalne, w zakresie wykorzystania zasobów pracy, przygotowania kadr w procesie kształcenia, dokształcania czy doskonalenia zawodowego. Dzięki wewnętrznym powiązaniom funkcjonalnym elementy o funkcjach podstawowych i komplementarnych mogą odgrywać ważną rolę czynników lokalizacji i rozwoju działalności gospodarczej podmiotów osób fizycznych oraz wpływać na wykształcanie się społecznych postaw przedsiębiorczych.

W strukturze regionalnej obok powiązań funkcjonalnych między poszczególnymi elementami zachodzą także relacje konkurencyjne w zakresie: wykorzystywania zasobów przyrodniczych, zajmowania niezagospodarowanej przestrzeni, przejmowania zasobów pracy, wykorzystania zasobów kapitałowo-finansowych osób fizycznych przez tworzenie podmiotów o mieszanym kapitale, zasobów intelektualnych umożliwiających zintensyfikowanie zakładania nowych działalności gospodarczych wymagających wyższych kwalifikacji zawodowych, infrastruktury techniczno-ekonomicznej i społecznej, wykorzystania zasobów instytucji kultury itd. Szczególne znaczenie dla rozwoju struktur regionalnych ma nasilająca się konkurencja w zakresie pozyskiwania wysoko kwalifikowanych zasobów pracy. Zasoby te najbardziej podatne są na procesy migracyjne do miejsc, gdzie istniejące rynki zapewniają im odpowiednie i bardziej konkurencyjne warunki pracy, atrakcyjniejsze miejsca zamieszkania, wyższe płace, możliwości rozwoju zawodowego i awansu ${ }^{6}$.

$\mathrm{Na}$ wzrost potencjału gospodarczego podmiotów gospodarczych główny wpływ wywierają rynki zbytu na oferowane przez nich produkty i usługi. Wśród nich można

\footnotetext{
${ }^{5}$ Funkcje te mogą także pełnić podmioty gospodarcze osób fizycznych, wymaga to jednak wysokich kwalifikacji zawodowych tych osób, np. firma trzyosobowa projektowa kominów dzięki wysokim kwalifikacjom właściciela wykonuje prace projektowe dla firm niemieckich czy tureckich; podobnie firma, której właściciel opatentował swój wynalazek, sprawdza jakość techniczną i stopień zużycia lin dźwigowych w budynkach wysokościowych w Europie, Azji i Ameryce.

${ }^{6}$ W 2016 r. najbardziej konkurencyjne w zakresie migracji było województwo mazowieckie, które charakteryzowało się dodatnim saldem migracji wynoszącym 11,1 tys. osób, a następnie województwo pomorskie (3,5 tys.), małopolskie (3,3 tys.), dolnośląskie (2,6 tys.) i wielkopolskie (1,0 tys.). Pozostałe województwa odznaczały się ujemnymi saldami migracji, a najwyższymi województwa: lubelskie (4,4 tys.), śląskie (3,4 tys.) i warmińsko-mazurskie (2,7 tys.).
} 
wyróżnić rynki: światowe, europejskie, rynek krajowy, regionalny i lokalny. Powiązaniami z wyróżnionymi kategoriami rynku mogą mieć także podmioty gospodarcze osób fizycznych. Konkurencyjność ich opiera się głównie na dobrej jakości oferowanych produktów, wykonywanych prac, zwłaszcza prac budowlanych, remontowych, porządkowych, obsługi ludzi starszych i in. Osoby te posiadają najczęściej odpowiednie kwalifikacje zawodowe zdobyte na różnym poziomie kształcenia od szkolnictwa zawodowego, przez średnie do szkolnictwa wyższego. Chociaż znaczna część tych prac wykonywana jest na zasadach „czarnego rynku”, to jednak aktywizują one zasoby pracy oraz umożliwiają zwiększenie strumieni finansowych wpływających do gospodarstw domowych ${ }^{7}$.

\section{Wpływ reguł ekonomicznych i polityki na działalność podmiotów gospodarczych}

Procesy gospodarcze funkcjonują według określonych reguł ekonomicznych. Działalność podmiotów gospodarczych prowadzona jest w oparciu o reguły mikroekonomiczne, a ich podstawowym celem jest osiąganie maksymalnego zysku. Wynika to z faktu, iż przedsiębiorca kierujący własną działalnością oraz dysponujący odpowiednim kapitałem nie tylko podejmuje samodzielnie decyzje w zakresie rozwijania działalności i zwiększania dochodów, ale także musi się liczyć z określonym ryzykiem. Trafne decyzje wpływają na wzrost efektywności, możliwości zwiększania potencjału ekonomicznego i rozwoju podmiotu gospodarczego, ale niewłaściwe decyzje generują określone straty kapitałowe i finansowe, mogą doprowadzić nawet do upadku podmiotu gospodarczego. Podmioty gospodarcze o dużym potencjale ekonomicznym zazwyczaj kreślą dalekosiężne plany rozwoju swojej działalności i rozwijania rynku, natomiast podmioty osób fizycznych o znacznie niższym potencjale ekonomicznym stawiają bliskie cele, dokonują często doraźnych transakcji i przygotowane są zazwyczaj na zmianę profilu działalności.

Działalność podmiotów gospodarczych prowadzona jest w określonych układach regionalnych, będących na różnym poziomie rozwoju, które rządzą się regułami mezoekonomicznymi. Te z kolei funkcjonują w strukturze gospodarki krajowej, która rządzi się regułami makroekonomicznymi. Unia Europejska skupiająca poszczególne kraje rządzi się regułami megaekonomicznymi, a ta z kolei kształtuje się w przestrzeni światowej, która rozwija się w oparciu o reguły ekonomii globalnej. Między poszczególnymi regułami rozwoju ekonomicznego zachodzą pewne konflikty, które wynikają z ich charakteru, np. przedsiębiorstwo dążące do maksymalizacji zysku chętnie ograniczałoby podatki odprowadzane do budżetu regionalnego czy krajowego, natomiast budżety regionalne czy krajowe chętnie zwiększałyby swoje wpływy z tytułu podatków. Podobnie poszczególne kraje chętnie by korzystały z dotacji unijnych, ale równocześnie dążą do ograniczania swoich wkładów do unijnego budżetu. Również wiele krajów, z różnych względów (np. w celu osłabienia konkurencji) wprowadza ograniczanie importowe przez cła lub ograniczanie importu tylko określonych produktów, natomiast eksporterzy chętnie zwiększaliby wielkości eksportu na ich rynki. Konflikty w tym zakresie należy traktować jako coś naturalnego, natomiast powinno się je niwelować w wyniku odpowiednich negocjacji. Te złożone procesy oddziałują także na podmioty gospodarcze osób fizycznych działających w układach regionalnych, np. tanie produkty płynące z Azji przyczyniły się do upadku

\footnotetext{
${ }^{7}$ Szacunki szarej strefy w krajach europejskich wahają się od 6\% w Szwajcarii i 7,1\% w Austrii do 26,5\% w Chorwacji i 29,6\% w Bułgarii, podczas gdy w Polsce wynosi ona 22,2\% (Cieślak-Wróblewska, 2018).
} 
wielu podmiotów gospodarczych, funkcjonujących uprzednio w układach regionalnych, np. branży odzieżowej, obuwniczej i in.

Znaczącą rolę w rozwoju przedsiębiorczości odgrywa polityka gospodarcza, społeczna, a także międzynarodowa, regionalna czy ekologiczna. Przez wdrażane instrumenty bezpośredniego i pośredniego oddziaływania można dla określonych rodzajów działalności gospodarczych stwarzać określone warunki dla pojawiania się nowych podmiotów gospodarczych bądź dla rozwoju podmiotów już istniejących, ale także można wpływać na ich stagnację, recesję, a nawet - zanikanie. Dlatego osobom fizycznym chcących podjąć działalność gospodarczą wiedza z tego zakresu jest niezbędna, ponieważ może uchronić je przed nieprzewidywanymi i negatywnymi skutkami inwestowania.

\section{Uwarunkowania społeczne rozwoju działalności gospodarczej osób fizycznych}

Przedstawione elementy struktury regionalnej reprezentują różne sektory gospodarki, odznaczają się określonymi czynnikami lokalizacji i rozwoju oraz spełniają różnorodne funkcje. W procesie ich kształtowania bardzo ważnym problemem jest umiejętne wykorzystanie reguł rozwoju ekonomicznego, w celu pobudzania i rozwijania działalności gospodarczej. Stąd znaczącą rolę w tym procesie odgrywa jakość elit politycznych władzy ustawodawczej, wykonawczej i sądowniczej, a także działalność organizacji o różnym zasięgu: światowym, europejskim, krajowym czy regionalnym. Brak wiedzy i umiejętności w tym zakresie sprawia, że elity chętniej zajmują się wieloma nieistotnymi problema$\mathrm{mi}$, na temat których wszyscy mogą dyskutować, zamiast na istotnych problemach dotyczących: wzrostu gospodarczego, wyrównywania różnic w potencjale ekonomicznym społeczeństwa, przewidywania kierunków zmian technologicznych, technicznych, rynkowych, ekologicznych i innych.

Podstawowe znaczenie ma również odpowiedź na pytanie, w jakim stopniu instrumenty organizacji światowych, unijnych, krajowych, regionalnych, a nawet lokalnych wpływają na procesy przemian działalności podmiotów gospodarczych oraz na ich przemiany funkcjonalne. $\mathrm{W}$ procesie rozwoju podmioty gospodarcze mogą wykazywać często odmienne tendencje przemian, które mogą przejawiać się w ich rozwoju, stagnacji, recesji czy nawet - zaniku. Mogą także pojawiać się nowe podmioty nawiązujące do pojawiających się nowych rynków czy postępującego rozwoju technologicznego i technicznego, wpływających na przyspieszanie procesów kształtowania gospodarki opartej na wiedzy (np. usługi informatyczne). Ważna w tym zakresie powinna być zasada, aby odpowiednio przewidywać zarysowujące się tendencje zmian i nawiązywać do chłonności nowych potencjalnych rynków. Wpłynie to na ograniczenie kosztów działalności gospodarczej, obieranie racjonalnych kierunków inwestowania oraz ograniczanie potencjalnego ryzyka ${ }^{8}$.

Procesami tymi zarządza odpowiednio wykształcony człowiek, dlatego ważnym zadaniem jest dbałość o wcześniejsze przygotowanie kadr pracowniczych, które będą wyposażone w odpowiednią wiedzę oraz umiejętności pozwalające na racjonalne stymulowanie procesami rozwoju firm i różnej skali układów przestrzennych, w tym układów regionalnych.

${ }^{8}$ W 2010 r. zarejestrowanych było 7,6 tys. e-sklepów, z których do końca stycznia 2018 r. prowadziło swoją działalności tylko 2,3 tys., czyli ubyło 30,3\% z nich. W latach 2013-2018 (styczeń) liczba e-sklepów wzrosła z 21,7 tys. do 29,1 tys., tj. do 134,1\%, z których około 30\% nie prowadzi działalności. W wyniku rozwoju technologicznego, drogich reklam, rosnących cen usług i prowizji operatorów, następuje koncentracja działalności w dużych jednostkach, co stanowi poważną barierę dla działalności mniejszych jednostek (Mazurkiewicz, 2018). 
Miejsce podmiotów gospodarczych w strukturze funkcjonalnej układu regionalnego

Lokalizacja i rozwój działalności podmiotów gospodarczych osób fizycznych dokonują się w wyniku wzajemnych powiązań produkcyjnych lub usługowych oraz pod wpływem ich otoczenia. Realizują się one przez zachodzące między nimi określone relacje aktywne i pasywne (tab. 1).

Relacje zachodzące między podmiotami gospodarczymi ilustruje macierz $\left[\mathrm{X}^{\mathrm{X}}\right]$. W wyniku różnorodnych wzajemnych powiązań mogą one stwarzać korzystne uwarunkowania dla rozwoju (wpływać na podbudzanie i dynamikę ich wzajemnego wzrostu), mogą rozwijać się niezależnie od siebie, ale także w wyniku relacji konkurencyjnych mogą wpływać na osłabianie dynamiki rozwoju lub prowadzić do ich upadku.

Podmioty gospodarcze w wyniku aktywnych relacji z otoczeniem oddziałują w różnorodnym zakresie na: poszczególne elementy przestrzeni regionalnej $\left[\mathrm{X}^{\mathrm{M}}\right]$, spełniane funkcje w strukturze regionalnej $\left[\mathrm{X}^{\mathrm{C}}\right]$, podnoszenie konkurencyjności zasobów regionalnych $\left[\mathrm{X}^{\mathrm{K}}\right]$, kształtowanie otoczenia rynkowego $\left[\mathrm{X}^{\mathrm{O}}\right]$, zmiany funkcjonowania $\mathrm{w}$ ramach reguł ekonomicznego rozwoju $\left[\mathrm{X}^{\mathrm{N}}\right]$, doskonalenie polityki gospodarczej $\left[\mathrm{X}^{\mathrm{O}}\right]$, jakość elit tworzących uwarunkowania dla ich funkcjonowania i elit zarządzających $\left[\mathrm{X}^{\mathrm{W}}\right]$, a także na proponowanie i wprowadzanie odpowiednich instrumentów prawnych likwidujących bariery i umożliwiających intensyfikację ich wzrostu $\left[\mathrm{X}^{\mathrm{S}}\right]$.

Natomiast w wyniku relacji pasywnych poszczególne elementy otoczenia oddziałują na podmioty gospodarcze. Wpływ przestrzeni regionalnej na podmioty gospodarcze ilustruje $\left[\mathrm{M}^{\mathrm{X}}\right]$, wpływ kształtujących się funkcji - $\left[\mathrm{C}^{\mathrm{X}}\right]$, wpływ możliwości wykorzystania zasobów regionalnych $-\left[\mathrm{K}^{\mathrm{X}}\right]$, wpływ otoczenia rynkowego $-\left[\mathrm{O}^{\mathrm{X}}\right]$, reguł rozwoju $-\left[\mathrm{N}^{\mathrm{X}}\right]$,

Tab. 2. Miejsce podmiotów gospodarczych osób fizycznych w strukturze funkcjonalnej układu regionalnego

\begin{tabular}{|c|c|c|c|c|c|c|c|c|c|c|}
\hline \multicolumn{2}{|c|}{ Elementy układu regionalnego } & $\mathrm{X}$ & M & C & $\mathbf{K}$ & 0 & $\mathbf{N}$ & $\mathbf{P}$ & $\mathbf{W}$ & S \\
\hline $\begin{array}{l}\text { Podmioty gospodarcze osób } \\
\text { fizycznych }\end{array}$ & $x$ & $x^{x}$ & $X^{M}$ & $X^{c}$ & $x^{k}$ & $X^{0}$ & $X^{N}$ & $X^{\mathrm{P}}$ & $x^{w}$ & $x^{s}$ \\
\hline Elementy przestrzeni regionalnej & M & $M^{x}$ & $\mathrm{M}^{\mathrm{M}}$ & $M^{c}$ & $M^{k}$ & $M^{0}$ & $M^{N}$ & $M^{P}$ & $M^{w}$ & $M^{s}$ \\
\hline $\begin{array}{l}\text { Funkcje elementów regionalnhych: } \\
\text { podmioty gospodarcze, instytucje }\end{array}$ & C & $C^{x}$ & $\mathrm{C}^{\mathrm{M}}$ & $C^{C}$ & $C^{k}$ & $\mathrm{C}^{0}$ & $C^{N}$ & $C^{p}$ & $C^{W}$ & $C^{S}$ \\
\hline $\begin{array}{l}\text { Konkurencyjność w wykorzystaniu } \\
\text { zasobów regionalnych }\end{array}$ & $\mathbf{K}$ & $\mathrm{K}^{\mathrm{X}}$ & $\mathrm{K}^{\mathrm{M}}$ & $K^{C}$ & $K^{K}$ & $\mathrm{~K}^{0}$ & $K^{N}$ & $K^{\mathrm{P}}$ & $\mathrm{K}^{\mathrm{W}}$ & $\mathrm{K}^{\mathrm{S}}$ \\
\hline Otoczenie rynkowe & 0 & $0^{x}$ & $0^{\mathrm{M}}$ & $0^{c}$ & $0^{\mathrm{k}}$ & $0^{0}$ & $0^{\mathrm{N}}$ & $0^{\mathrm{P}}$ & $0^{w}$ & $0^{\mathrm{s}}$ \\
\hline Reguły rozwoju ekonomicznego & $\mathbf{N}$ & $\mathrm{N}^{\mathrm{x}}$ & $\mathrm{N}^{\mathrm{M}}$ & $\mathrm{N}^{\mathrm{C}}$ & $\mathrm{N}^{\mathrm{K}}$ & $\mathrm{N}^{0}$ & $\mathrm{~N}^{\mathrm{N}}$ & $N^{P}$ & $N^{W}$ & $\mathrm{~N}^{\mathrm{S}}$ \\
\hline $\begin{array}{l}\text { Polityka: światowa, europejska, } \\
\text { krajowa, regionalna }\end{array}$ & $\mathbf{P}$ & $\mathrm{px}^{\mathrm{x}}$ & $\mathrm{PM}$ & $\mathrm{PC}$ & $\mathrm{PK}^{\mathrm{K}}$ & $\mathrm{P}^{0}$ & $\mathrm{P}^{\mathrm{N}}$ & $P^{P}$ & $\mathrm{P}^{w}$ & ps \\
\hline $\begin{array}{l}\text { Jakość elit politycznych władzy: } \\
\text { ustawodawczej, wykonawczej, } \\
\text { sądowniczej }\end{array}$ & W & $W^{x}$ & $W^{M}$ & $W^{C}$ & $W^{k}$ & $W^{0}$ & $W^{N}$ & $W^{P}$ & $W^{w}$ & $W^{s}$ \\
\hline $\begin{array}{l}\text { Instrumenty prawne: pobudzające, } \\
\text { stymulujące, hamujące }\end{array}$ & $\mathbf{S}$ & $S^{x}$ & $S^{M}$ & $S^{C}$ & $S^{K}$ & $\mathrm{~S}^{0}$ & $S^{N}$ & $S^{p}$ & $S^{w}$ & $S^{s}$ \\
\hline
\end{tabular}

Źródło: opracowanie własne 
określonej polityki - $\left[\mathrm{P}^{\mathrm{X}}\right]$, jakości elit politycznych - $\left[\mathrm{W}^{\mathrm{X}}\right]$ oraz oddziaływania instrumentów prawnych $-\left[\mathrm{S}^{\mathrm{x}}\right]$.

Oznacza to, że relacje $\left[\mathrm{X}^{\mathrm{O}}\right]$ i $\left[\mathrm{O}^{\mathrm{X}}\right]$ nie są sobie równe, ale określają odpowiednio aktywne $\left[\mathrm{X}^{\mathrm{O}}\right]$ i pasywne $\left[\mathrm{O}^{\mathrm{X}}\right]$ relacje podmiotu gospodarczego $\mathrm{z}$ elementami przestrzeni regionalnej. Zmiany potencjału i funkcji danego podmiotu gospodarczego oddziałują zatem na pozostałe podmioty gospodarcze oraz poszczególne elementy układu regionalnego, a także odwrotne zmiany pozostałych podmiotów gospodarczych i otoczenia regionalnego oddziałują na dany podmiot gospodarczy. Dokonuje się to w wyniku nowych lokalizacji oraz rozwijania lub zmiany profilu działalności przez dany podmiot gospodarczy. Oznacza to, że przemiany wielkości potencjału gospodarczego i funkcji podmiotów gospodarczych wpływają na pozostałe elementy układu regionalnego i w zasadniczym stopniu oddziałują na kształtowanie struktury regionalnej, ale także, że elementy układu regionalnego oddziałują na podmioty gospodarcze.

W otoczeniu podmiotu gospodarczego zaznaczają się też różnego rodzaje relacje zachodzące między pozostałymi elementami układu regionalnego. Na przykład aktywne oddziaływanie różnych rodzajów polityki wpływa na elementy przestrzeni regionalnej, co ilustruje [PM], czy na otoczenie rynkowe [PO], ale również elementy przestrzeni regionalnej oddziałują na rodzaje polityki [MP], podobnie jak i otoczenie rynkowe [OP]. W ten sposób możemy określić różnorodne relacje aktywne i pasywne zaznaczające się między wszystkimi elementami układu regionalnego.

Dla racjonalnego zarządzania rozwojem społeczno-gospodarczym i kulturowym układów regionalnych niezbędne jest precyzyjne poznanie kształtujących się w ich strukturze relacji zachodzących między poszczególnymi podmiotami gospodarczymi, w tym podmiotami osób fizycznych oraz elementami układów regionalnych. Pozwala to na: ocenę dotychczasowego procesu przemian, określanie możliwości lokalizacji i rozwoju działalności podmiotów gospodarczych, właściwe kształtowanie instytucji, przewidywanie możliwości zmian procesów gospodarczych, społecznych i kulturowych pod wpływem działań określonych instrumentów polityki, ocenę jakości elit regionalnych oraz transformacji otoczenia.

\section{Uwagi końcowe}

W świetle przedstawionych rozważań należy przyjąć, że funkcjonowanie i rozwój podmiotów gospodarczych osób fizycznych odbywa się w złożonej strukturze układów regionalnych. Podstawowym celem ich działalności jest maksymalizacja zysków w wyniku podnoszenia jakości oferowanych produktów, wpływanie na wzrost poziomu i jakości życia mieszkańców, a także na zwiększanie konkurencyjności układów regionalnych. Są one ważnymi elementami struktury regionalnej, spełniając głównie funkcje lokalne i regionalne, przez co są ważnym uzupełnieniem regionalnej lokalnej bazy ekonomicznej, którą w głównym stopniu tworzą elementy podstawowe i komplementarne. Lokalizacja i przemiany funkcjonalne podmiotów gospodarczych związane są z uwarunkowaniami, które tworzą elementy otoczenia (przyrodnicze, społeczne i kulturowe, jakość zasobów regionalnych i in.). Kształtują się one według mikroekonomicznych reguł rozwoju, podczas gdy układy regionalne kształtują się według reguł mezoekonomicznych. Dlatego naturalną rzeczą jest pojawianie się między nimi konfliktów, które należy ograniczać w drodze negocjacji. 
Na procesy i poziom rozwoju zróżnicowanych wewnętrznie układów regionalnych wpływają także jakość otoczenia instytucjonalnego oraz sprawność i zasoby intelektualne przedstawicieli elit samorządowych, politycznych i organizacji pozarządowych. Funkcjonują one na podstawie wdrażanych zasad instrumentów bezpośredniego i pośredniego oddziaływania kreowanych w skali regionalnej, krajowej, Unii Europejskiej i organizacji międzynarodowych. Dla racjonalnych procesów zarządzania i dynamizowania rozwoju układów regionalnych niezmiernie ważnym zadaniem jest stwarzanie najdogodniejszych warunków dla pobudzania i wzrostu przedsiębiorczości przez osoby fizyczne oraz podmioty gospodarcze, które muszą podejmować decyzje inwestowania i prowadzenia działalności gospodarczej, uwzględniając przy tym określone ryzyko.

Między zróżnicowanymi układami regionalnymi a procesami rozwoju przedsiębiorczości zachodzą określone relacje, pasywne i aktywne. Poznanie ich w znacznym stopniu może wpływać na sprawniejsze zarządzanie i podnoszenie efektywności gospodarowania w układach regionalnych. Pozwoli to na realizację ostatecznego celu, jakim jest podnoszenie jakości i poziomu życia społeczeństwa.

W prowadzeniu działalności gospodarczej osoby wykorzystują swoje kwalifikacje zawodowe i doświadczenie zdobyte w wyniku: formalnej edukacji, przyuczenia się do nowego zawodu na różnych kursach, w firmie lub w drodze samokształcenia.

Podmioty gospodarcze osób fizycznych oferują prace wymagające różnych kwalifikacji i umiejętności zawodowych. Obejmują one:

- usługi powszechnie występujące bez konieczności posiadania kwalifikacji zawodowych (prace porządkowe, pomoc w budownictwie i gospodarstwie domowym, praca sezonowa w rolnictwie, opieka nad dziećmi i in.),

- usługi wymagające określonych umiejętności i doświadczenia, takie jak: obsługa finansowa, naprawa sprzętu gospodarstwa domowego, urządzeń elektronicznych, szycie, reperacja odzieży, obuwia, usługi budowlane, remonty, usługi transportowe i in.,

- usługi sporadycznie występujące, wymagające wysokich kwalifikacji i umiejętności: usługi medyczne, prawnicze, finansowa obsługa firm, nauka języków obcych, korepetycje najczęściej z przedmiotów ścisłych, prace budowlane i instalacyjne, geodezyjne, projektowe, konserwatorskie, zajęcia artystyczne,

- produkcję rzemieślniczą obejmującą wyroby powszechnego użytku, wyroby artystyczne, wyroby nietypowe specjalnego przeznaczenia i in.

Wśród głównych motywów formalnego zakładania działalności gospodarczej najczęściej wymieniane to: chęć pracy na własny rachunek, możliwość uzyskania wyższych zarobków, nieograniczony czas pracy, wykorzystanie własnych umiejętności, własnych zasobów kapitałowych, finansowych i infrastrukturalnych. Działalność podmiotów gospodarczych może mieć charakter ciągły, sezonowy związany z określonymi warunkami rynku pracy (np. w rolnictwie, ogrodnictwie), może także wynikać ze zmieniających się chęci i upodobań właściciela.

Natomiast działający w szarej strefie, często obok stałej pracy w innej firmie czy instytucji, na pierwszy plan wysuwają chęć zwiększania środków finansowych płynących do budżetu domowego. Ważnymi czynnikami podejmowania pracy jest rozmiar rynku na oferowane produkty i usługi oraz pracowitość i chęć podniesienie standardu życia danej osoby i jej rodziny (np. korepetycje, usługi elektryczne, komputerowe, proste domowe prace remontowe itp.). 
Działalność podmiotów gospodarczych osób fizycznych w zasadniczym stopniu zależy od rynku, którego rozmiary wynikają z potencjału zasobów finansowych podmiotów gospodarczych i instytucji, dla których są one najczęściej podwykonawcami w zakresie wytwarzania określonych elementów, wykonywania usług remontowo-budowlanych oraz od zasobów finansowych gospodarstw domowych, które mogą im także zlecać wytwarzanie różnych produktów i wykonanie określonych usług. Przy czym rosnące zasoby finansowe znacznie rozszerzają rynki na określone usługi czy zakup produktów. Natomiast kurczące się zasoby finansowe rynek ten ograniczają w wyniku: rezygnacji z ewentualnych zakupów określonych produktów i wykonywania prac, odkładania ich na późniejszy termin lub wykonywania prac przez członków rodziny (np. prace porządkowe, remontowe, naprawa sprzętu, często przy konieczności zdobywania nowych umiejętności). Podmioty działające w szarej strefie podnoszą swoją konkurencyjność w wyniku oferowania niższych cen za produkty i usługi, dzięki omijaniu instytucji fiskalnych, które muszą uwzględniać podmioty formalnie prowadzące swoją działalność.

Należy podkreślić, iż brak podstawowej wiedzy w zakresie lokalizacji i podejmowania działalności podmiotów gospodarczych osób fizycznych często prowadzi do ich upadku oraz ponoszenia określonych strat w wyniku nieuwzględnienia ryzyka wynikającego $\mathrm{z}$ istniejących współcześnie oraz zmieniających się w najbliższej przyszłości uwarunkowań lokalnych, regionalnych, krajowych, a nawet - międzynarodowych.

\section{Literatura}

References

Bajgier-Kowalska, M., Tracz, M., Uliszak, R. (2016). Uwarunkowania rozwoju przedsiębiorczości na obszarach wiejskich na przykładzie gospodarstw agroturystycznych województwa małopolskiego. Przedsiębiorczość - Edukacja, 12, 256-273.

Berezowski, S. (1988). Regionalizacja społeczno-gospodarcza. Warszawa: SGPiS.

Cieślak-Wróblewska, A. (2018). Szara strefa w Polsce. Rzeczpospolita. 7 marca.

Dobrowolska, M. (1948). Dynamika krajobrazu kulturalnego. Przegląd Geograficzny, XXI(3-4), 151-203.

Dobrowolska, M. (1962). Czynniki kształtowania się, przeobrażania i rozpadu społeczno-ekonomicznych struktur regionalnych. Księga pamiątkowa ku czci prof. dra Wt. Antoniewicza, t. XXIV, Warszawa: „Światowid”, 127-158.

Dominiak, J. (2016). Rola otoczenia biznesu we wspieraniu przedsiębiorczości i innowacyjności gospodarki. Przykład Wielkopolski. Przedsiębiorczość - Edukacja, 12, 98-113.

Dziewoński, K. (1971). Baza ekonomiczna i struktura funkcjonalna. Prace Geograficzne, 87.

Fajferek, A. (1966). Region ekonomiczny i metody analizy regionalnej. Warszawa: PWE.

Harańczyk, A. (2011). Perspektywy rozwoju regionalnego Polski w okresie programowania po 2013 r., cz. I. Studia Komitetu Przestrzennego Zagospodarowania Kraju. PAN, CXL, Warszawa.

Harańczyk, A. (2012). Perspektywy rozwoju regionalnego Polski w okresie programowania po 2013 r., cz. II, Studia Komitetu Przestrzennego Zagospodarowania Kraju. PAN, CXL.

Kamińska, W., Heffner, K. (red.) (2010). Kapitał ludzki i społeczny w procesie rozwoju obszarów wiejskich. Studia Komitetu Przestrzennego Zagospodarowania Kraju. PAN, CXXVII.

Kiniorska, I., Wrońska-Kiczor, J. (2016). Przedsiębiorczość jako czynnik rozwoju terenów wiejskich województwa świętokrzyskiego. Przedsiębiorczość - Edukacja, 12, 36-51.

Kudełko, J. (2003). Położenie centrów wzrostu społeczno-gospodarczego wschodniego pogranicza jako wyraz kształtującego się ładu przestrzennego. Biuletyn Komitetu Przestrzennego Zagospodarowania Kraju. PAN, 205, 176-182. 
Kudełko, J. (red.) (2007). Uwarunkowania rozwoju rzeszowskiego obszaru metropolitarnego w systemie społeczno-gospodarczym i innowacyjnym województwa podkarpackiego. Polska Akademia Nauk Oddział w Krakowie, Prace Komisji Nauk Ekonomicznych, 25.

Kudełko, J. (2013). Uwarunkowania rozwoju województw Polski Wschodniej jako regionów słabo rozwiniętych. Studia Komitetu Przestrzennego Zagospodarowania Kraju. PAN, CLI.

Kudłacz, T. (1999). Programowanie rozwoju regionalnego. Warszawa: PWN.

Maciejewicz, P. (2018). Bogaci pompują majątki. Rzeczpospolita, 22 stycznia.

Mazurkiewicz, P. (2018). Większość nowych sklepów internetowych szybko znika z rynku. Rzeczpospolita, 22 marca.

Pasierbek, W., Wach, K. (red.). (2016). Uniwersytet a przedsiębiorczość. Horyzonty Wychowania, 15(35), 5-6.

Płaziak, M., Rachwał, T. (2014). The Role of Entrepreneurship in Regional Development Strategies (based on the Polish National Strategy of Regional Development 2010-2020). Europa XXI, 26, 97-110.

Płaziak, M., Rachwał T. (2015). „Przedsiębiorczy region” - zarys koncepcji w świetle analizy roli przedsiębiorczości w krajowej strategii rozwoju regionalnego. Przedsiębiorczość - Edukacja, 11, 37-49.

Sowislok, K. (2016). Rola Zabrzańskiego Centrum Rozwoju Przedsiębiorczości w rozwoju lokalnej przedsiębiorczości. Przedsiębiorczość - Edukacja, 12, 123-133.

Śleszyński, P., Bański, J., Degórski, M., Komornicki, T. (2017). Delimitacja obszarów strategicznej interwencji państwa: obszarów wzrostu i obszarów problemowych, Prace Geograficzne, 260.

Wach, K. (2015). Przedsiębiorczość jako czynnik rozwoju społeczno-gospodarczego: przegląd literatury. Przedsiębiorczość - Edukacja, 11, 24-36.

Wach, K. (2014a) (red.). Edukacja dla przedsiębiorczości. Horyzonty Wychowania, 13(26), 5-6.

Wach, K. (2014b). Przedsiębiorczy uniwersytet. Horyzonty Wychowania, 13(28), 3-6.

Zaucha, J., Szlachta, J. (2015). Terytorialny wymiar wzrostu i rozwoju. Warszawa: Difin.

Zioło, Z. (2010). Rola zasobów intelektualnych, kapitału ludzkiego i społecznego w procesach rozwoju obszarów wiejskich. Studia Komitetu Przestrzennego Zagospodarowania Kraju. PAN, CXXVII, 9-28.

Zioło, Z. (2015). Przedsiębiorczość jako czynnik rozwoju społeczno-gospodarczego układów przestrzennych. Przedsiębiorczość - Edukacja, 11, 7-23.

Zioło, Z. (2016). Przedsiębiorczość w rozwoju układów lokalnych. Przedsiębiorczość - Edukacja, 12, 6-17.

Zioło Z. (2017). Problematyka regionalizacji i regionu społeczno-gospodarczego jako przedmiot poznania i zarządzania. Zeszyty Naukowe Podkarpackiej Szkoły Wyższej im. Bł. Ks. W. Findysza w Jaśle, 9-29.

Zbigniew Zioło, prof. dr hab., Uniwersytet Pedagogiczny im. Komisji Edukacji Narodowej w Krakowie, Instytut Geografii, Zakład Przedsiębiorczości i Gospodarki Przestrzennej. Podkarpacka Szkoła Wyższa im. bł. ks. Władysława Findysza w Jaśle. Doktor nauk przyrodniczych, dr hab. i profesor nauk ekonomicznych. Jego zainteresowania badawcze to: gospodarka przestrzenna, geografia ekonomiczna, polityka społeczno-gospodarcza, ekonomika i polityka rozwoju regionalnego.

Zbigniew Zioło, professor, the Pedagogical University of Cracow, Institute of Geography, the Department of Entrepreneurship and Spatial Management. Podkarpacka Higher Education School in Jasło. He holds a DSc title. He is also a professor of Economics. His research interests include: land management, economic geography, socio-economic policies, economics and policies of regional development.

\section{Adres/Address:}

Uniwersytet Pedagogiczny im. Komisji Edukacji Narodowej w Krakowie

Instytut Geografii

Zakład Przedsiębiorczości i Gospodarki Przestrzennej

ul. Podchorążych 2

30-084 Kraków, Polska

e-mail: zbziolo@onet.eu 